\title{
Creativity and Education
}

\author{
Robina Shaheen \\ School of Education, University of Birmingham, Birmingham, UK. \\ Email: robina149@hotmail.com \\ Received July $9^{\text {th }}, 2010$; revised September $1^{\text {st }}, 2010$; accepted September $21^{\text {st }}, 2010$.
}

\begin{abstract}
This paper starts with a brief background of the link between creativity and education, including the beginning of the most recent interest in the two. There is a short summary of the reasons for this renewed interest. This is followed by a discussion into the dissatisfactions over current education and its changing role in the light of increasing importance being accorded to creativity. Lastly, evidence in educational policy documents from around the world is presented to show the steps being taken for implementation of creativity in education.
\end{abstract}

Keywords: Creativity, Primary Education, Policy, Curriculum, Developing Countries

\section{The Link between Creativity and Education}

Although the interest in creativity goes back to Plato's age (Cropley, 2004) and is found in the Greek, Judaic, Christian and Muslim traditions, (Craft, 2001) renewed policy interest came about with the launch of satellite, "Sputnik 1", by the Soviet Union in 1957. The purported failure of the engineers from Europe, USA and other Western countries was attributed to their lack of creativity which led to the National Defense Education Act (USA) to accept the concept as important for "prosperity...survival of society" (Esquivel, 1995). Since this there have been several "waves of creativity in education" (Wilson, 2005). The latest interest, however, began in the late 90's (Jeffrey, 2005) and has since been growing (Turner-Bisset, 2007) throughout the world, including countries such as the USA and UK (Shallcross, 1981; Feldman et al, 2006). Policymakers have shown more sustained enthusiasm than previously (Craft, 2006), which has added to its popularity as a topic of debate (Dickhut, 2003) moving it from the "fringes of education...to being seen as a core aspect of educating" (Craft, 2005).

Fostering creativity in education is intended to address many concerns. As a summary, this includes dealing with ambiguous problems, coping with the fast changing world and facing an uncertain future (Parkhurst, 1999). Perhaps the most dominant current argument for policy is the economic one. The role of creativity in the economy is being seen as crucial (Burnard, 2006) to assist nations for attaining higher employment, economic achievement (Davies, 2002) and to cope with increased competition. It is for this reason that creativity cannot be "ignored or suppressed through schooling" (Poole, 1980) or its development be left to "chance and mythology" (NESTA, 2002). It is predominantly for this reason that there is a call for its inclusion in education as a "fundamental life skill" (Craft, 1999) which needs to be developed to prepare future generations (Parkhurst, 1999) so that they can "survive as well as thrive in the twenty-first century" (Parkhurst, 2006). Developing children's creativity during their years in education is the start of building "human capital" upon which, according to Adam Smith and successive commentators, depends the "wealth of nations" (Walberg, 1988).

\section{Changing role of Education}

Formal education "represents both a right and need" (Carnoy, 2004) but it has time and time again been criticized for turning out "conformists" and "stereotypes" rather than "freely creative and original thinkers" (Rogers, 1970). The role of education institutions has been questioned (Craft, 1999) and blamed for "spoon feeding" (Parnes, 1970) and "killing" creativity (Kaila, 2005). The increased pressures to gear education towards the "3 R's" and meeting the requirements of national curriculum, inspections and monitoring has led to the feeling, for some, that creativity in teaching and learning has ceased to exist and this will prevent governments from achieving a "creative society" (Grainger, 2004). One of the reasons why education systems have been regarded as barriers to developing and "releasing creative potential in the economy" is that the teaching focuses on "knowledge acquisition" (Davies, 2002). Knowledge, as an outcome of education is said to be no longer sufficient (Scoffham, 2003; Guilford, 1975). This is because it is difficult to know what knowledge will be needed in the future (Parnes, 1970).

If nations are to respond to "economic needs" (Craft, 2005) they need to produce an "educated workforce." Inevitably, this requires a rise in the level of educational achievement (Jeffrey, 2006). But what are being considered as criteria of educational achievement are said to be changing (Wilson, 2005) and being "reconceptualized...[to] encompass creativity" (Craft, 2001). In the light of this, education systems are being required to undergo "a major overhaul in resources, attitude and understanding" so that creativity can be valued (Turner-Bisset, 2007). As a response to such calls there has been a shift in educational policy around the world and efforts are being made to combine creativity and knowledge (Dickhut, 2003). Creativity is being made the focus of "curriculum and pedagogy" (Wilson, 2005) and an "official agenda" for improving schools (Burnard, 2006).

Schools are being seen as places for the encouragement of creativity because they can do this in a "more efficient" manner and can develop it "not merely in elites but in masses of students" (Walberg, 1988). In fact it is being said that creativity needs to be "fostered by the education system(s) from the early 
years onward" (Craft, 1999) and that elementary and secondary education may be more important than university education for "national prosperity and welfare" (Walberg, 1988). Primary education is being seen as:

.... critical stage in children's development - it shapes them for life. As well as giving them the essential tools for learning, primary education is about children experiencing the joy of discovery, solving problems, being creative in writing, art, music, developing their self-confidence as learners and maturing socially and emotionally (DCSF, 2003).

\section{The Inclusion of Creativity Within Education}

The inclusion of creativity into educational policy documents is evidence of the fact that the focus on creativity is not merely a matter of paying "lip service" to the concept (Csikszentmihalyi, 1996; Hussain, 2004) but rather action is being taken. O'Donnell and Micklethwaite (O'Donnell, 1999) reviewed the curriculum documents of 16 (developed) countries, (American, European and East Asian), identifying the place of arts and creativity in education. They found that creativity was included at various educational levels, at least from early years through primary education for most countries and beyond, up to higher education, for some.

In Canada "creative thinking" is outlined as one of the common essential learning(s) (p.8). In Kentucky, USA, one of the learning goals is to enable students to "use creative thinking skills to develop or invent novel, constructive ideas or products" (p.57). In Korea the National Curriculum defines an educated person as "healthy, independent, creative and moral" (p.33). In Sweden the Government's National Development Plan for Pre-School, School and Adult Education (1997) stated that education should provide "the conditions for developing creative skills" (p.52). In France schools in lower secondary are expected to develop in children the "taste for creation." (p.14). In Germany, the emphasis of primary education is placed on developing "children's creative abilities" (p.20). In Netherlands one of the principles on which primary education is based is “creative development" (O'Donnell \& Micklethwaite 1999, p.38). In Florida (USA) one of the goals of restructuring the schools was to provide students opportunities "to learn and apply strategies for creative...thinking" (Treffinger, 1996). The second educational goal for young people in Australia is to:

...become successful learners, confident and creative individuals, and active and informed citizens (ACARA, 2009).

In Japan the school curriculum has included development of creativity since the Second World War. The Japanese National Council on Educational Reform (NCER) has outlined the development of creativity as the most important objective of education for $21^{\text {st }}$ century (O'Donnell, 1999). In Singapore the aim of new initiatives, launched by the Ministry if Education, was to foster, "enquiring minds, the ability to think critically and creatively" (O'Donnell, 19990). These initiatives included the "Thinking Schools, Learning Nation" (TSLN) program (Tan, 2006) designed to develop thinking skills and creativity in students. This was in response to leading industrialists and entrepreneurs indicating that staff in Singapore was more "conforming" than "independent" and "not curious enough" (Tan, 2006). The Singapore Ministry of Education website states that they expect of their young to "be creative and imaginative"
(MOE, 2009). According to Singapore's primary curriculum creativity is amongst the eight core skills and values (INCA, 2009).

In China creativity has become an important component of education since 2001 and its development has become a "priority" (Vong, 2008). In Hong Kong the education policy proposal includes creativity as "higher order thinking skills". There are educational reforms being carried in preschool, primary and secondary education in which development of creativity is being given a "top priority" (Fryer, 2003). In Turkish education the concept of creativity is being discussed more and more, however attempts to enhance it through education are limited (Oral, 2008). In Ireland a strategy paper was developed called "Unlocking Creativity" for developing creativity and education (Robinson, 2001). In the Cultural Policy Statement by the Scottish Executive the Minister for Tourism, Culture and Sport spelt out his "vision" regarding creativity, in that:

Our devolved government should have the courage and the faith to back human imagination, our innate creativity, as the most potent force for individual change and social vision. I believe we should make the development of our creative drive the next major enterprise for our society...I believe this has the potential to be a new civic exercise on a par with health, housing and education - the commitment to providing and valuing creative expression for all.

The Policy Statement goes on to say that:

The creativity of Scots - from the classroom to the boardroom - is the edge we need in a competitive world. Our duty as an Executive is to create the conditions that allow that creativity to flourish - whether in arts, sciences, commerce or industry. Creativity is as valuable in retail, education, health, government and business as in culture. The cultural sector should become the national dynamo of the creative impulse that can serve all these areas (Scottish Executive, 2004).

Scotland is one of four home countries in the UK. In the 1990 's a number of policy documents and statements emerged for UK home countries which included creativity (Craft, 2001). In 1997 the White Paper, Excellence in Schools, referred to preparing people for the 21 st century by recognizing their "different talents". This was built upon by another report by the National Advisory Committee on Creative and Cultural Education (NACCCE, 1999) which spoke of equipping young children with skills required by employees (Craft, 2005). The NACCCE report acknowledged the UK government's views that creativity "was relevant to schools" (Jeffrey, 2005). This increased interest in the topic, bringing it back "on the agenda in a big way" (Brundrett, 2007). These mentioned documents provided the "foundation" for the recent policy discussions (Craft, 2005) in which the British Government responded to "debates about creative...education to meet the economic, technological and social challenges of the 21 st century" (Loveless, 2002).

Another document which called for creativity in primary education was the National Primary Strategy for primary schools, Excellence and Enjoyment, (Hayes, 2004). The Office for Standards in Education (Ofsted) published this report in 2003 and in this they identified creativity as "a significant factor in educational experience" (Jeffrey, 2005). This document, it is said, added a "conviction" that it is time for "a new, more creative approach to curriculum planning and a greater empha- 
sis on creativity for learning" (NCSL, 2004). There were also literature reviews on creativity supported by the Qualification and Curriculum Authority (QCA) and reports on the national Curriculum as well as a "criteria" for ensuring creativity was included in every subject (Jeffrey, 2005; Turner-Bisset, 2007). A website was established under the name of "Creativity: Find it! Promote it!" to enable teachers to find and promote creativity in the classroom (Burnard, 2006).

Creativity has become a focus in the curriculum as evident in its inclusion in the Foundation Stage Curriculum and National Curriculum for schools in England (Talboys, 2004; Craft, 2003). On the website for the National Curriculum, Key Stage 1 and 2 , there is a section on creativity which includes information on:

- What is creativity?

- Why is creativity important?

- How you can spot creativity?

- How can teachers promote creativity?

- How can heads and managers promote creativity? (QCDA, 2009)

In the National Curriculum itself Aim One is that the school should:

Enable pupils to think creatively and critically, to solve problems and to make a difference for the better. It should give them the opportunity to become creative, innovative, and enterprising (QCDA, 2009).

The National Curriculum outlines six "key skills" and amongst these is "thinking skills". Included in this is "creative thinking" which it is said "enable pupils to generate and extend ideas, to suggest hypotheses, to apply imagination, and to look for alternative innovative outcomes" (QCDA, 1999). This is regarded as one of the skills which are "universal" and "embedded in the subjects of the National Curriculum and are essential to effective learning." As an example of inclusion of creativity in the subjects it is stated in the science curriculum that:

Science stimulates and excites pupils' curiosity about phenomenon and events around in the world around them. It satisfies this curiosity with knowledge. Because science links direct practical experience with ideas, it can engage learners at many levels. Scientific method is about developing and evaluating explanations, through experimental evidence and modeling. This is a spur to critical and creative thought (QCDA, 1999).

There has also been investment in staff development and creating teaching resources. The UK government has moved beyond policy level work to initiate projects to provide and enhance "creative experiences" (Loveless, 2002) to learners by establishing projects under the "Creative Partnerships" schemes (Hayes, 2004). In this the schools are provided with opportunities to work with organizations such as dance studios and film makers through partnerships (Jeffrey, 2005). These efforts and "massive investments" have brought creativity to the forefront (Feldman, 2006).

\section{Conclusion}

It appears from what has been documented in the literature that the recent upsurge in creativity and education has taken place in European, American, Australian and East Asian countries, as reflected in their policy documents. This is further evidenced by the fact that some have stated that creativity has come to be seen as "key to economic competitiveness in advanced economies" (highlighted by researcher) (NESTA, 2002) implying that this is not so the case in less advanced economies. In referring to Tony Blair, (the former British Prime Minister), who it is reported "couples creativity in education to the future needs of the national economy" Gibson says that in this "the assumption...is that the production of a new, adaptive work force...is the sole way forward if Western economies, (highlighted by researcher), are to remain buoyant in future global contexts" (Gibson, 2005). Does this then mean that developing or non-western countries do not want to economically compete, do not need a new type of labor force, do not face any of the problems indicated, all of which, as it has already been argued, require creativity. In this Oral is of the view that:

For many developing countries, creativity remains neglected, whereas in developed countries, educational philosophy and goals rely on student's enhancement of creativity and self-actualization...For developing countries, integration of creative thinking skills in...education is a crucial need for shaping their future orientations and actualizing reforms in political, economic and cultural areas (Oral, 2006).

Sinlarat, speaking of Asian countries, is of the view that the Asians are "consumers" of Western products. This has resulted in loss of "self-identity" "self-independence" and "prosperity". He goes onto say that in order to overcome the dependency there is a need for Asians to become "creative and productive persons" and in this "education that yields creativity and productivity is essential for Asia". It is suggested that rather than taking what UNESCO states should be taught:

Learning how to learn

Learning how to do

Learning how to work together

Learning how to be

The following characteristics must be produced in people:

Learning how to learn critically

Learning how to do creatively

Learning how to work constructively

Learning how to be wise

It is said that:

Educational process primarily needs to set a target on new thinking and creativity for it to make education have the real effect on the society...Asia must adapt itself to be free, must have the advanced and creative way of life and must be able to give a push in the direction of globalization. These will happen when Asian education and society develop into truly creative and productive society and when Asia resists adopting ideas and copying knowledge from other countries as is the present case (Sinlarat, 2002).

To say for certain what Asian countries are doing regarding creativity and education and what they may need to do there is need for further research. Only by taking this approach will it be possible to say for sure that creativity is actually a "worldwide phenomenon" (Boyd, 2009) and the need for it in education is being recognized globally to solve the current problems facing societies.

This paper has outlined the various arguments given in literature for the need to couple creativity and education. Also included has been the evidence from policy documents from various countries to indicate that practical steps are being taken to make creativity part of the educational agenda. 


\section{References}

ACARA (2009). The Shape of the national curriculum. Internet Available:www.acara.edu.au/verve/_resources/The_Shape_of_the_Nation al_Curriculum_paper.pdf

Boyd, B. (2009). Caught in the headlights: Seeking permission to be creative within the Scottish education system, fostering creativity in learning in Scotland. Internet Available: www.opencreativity.open.a c.uk/assets/pdf/strathclyde/Caught $\% 20 \mathrm{in} \% 20$ the $\% 20$ headlights.pdf

Brundrett, M. (2007). Bringing creativity back into primary education. Education 3-13, 35, 105-107.

Burnard, P. (2006). Reflecting on the creativity agenda in education. Cambridge Journal of Education, 36, 313-318. doi:10.1080/03057640600865801

Craft, A. (1999). Creative development in the early years: Some implications of policy for practice. The Curriculum Journal, 10, 135-150.

Craft, A. (2001). An analysis of research and literature on creativity in education. Qualifications and Curriculum Authority.

Craft, A. (2003). The limits to creativity in education: Dilemmas for the educator. British Journal of Educational Studies, 51, 113-127. doi:10.1111/1467-8527.t01-1-00229

Craft, A. (2005). Creativity in schools: Tensions and dilemmas. Keynote paper presented at Creativity; Using it Wisely? part of ESRC creativity in education seminar series, University of Cambridge.

Craft, A. (2006). Fostering creativity with wisdom. Cambridge Journal of Education, 36, 337-350. doi:10.1080/03057640600865835

Cropley, A. (2004). Creativity as a social phenomenon. In: M. Fryer, (Ed.), Creativity and Cultural Diversity (pp.13-23). The Creativity Centre Educational Trust Press., England,

Carnoy, M. (2005) Paper commissioned for the EFA Global Monitoring Report 2005: The quality imperative, UNESCO.

Csikszentmihalyi, M. (1996). Creativity, flow and the psychology of discovery and invention. New York: Harper Collins.

DCSF (2003). Excellence and enjoyment: A strategy for primary schools. Internet Available: www.nationalstrategies.standards.dcsf.gov. uk/node $/ 85063$

Davies, D. Creative teachers for creative learners - a literature review. Undated, Internet Available: www.ttrb.ac.uk/attachments/ c30 96c7b -da04-41 ef-a 7ac-50535306e8fb.pdf.

Dickhut, J. (2003). A brief review of creativity. Internet Available. www.personalityresearch.org/papers/dickhut.html

Esquivel, G. (1995). Comment and reflection. Educational Psychology Review, 7, 215-218. doi:10.1007/BF02212496

Feldman, D., \& Benjamin, A. (2006) Creativity and education: An American retrospective. Cambridge Journal of Education, 36, 319-336. doi:10.1080/03057640600865819

Fryer, M. (2003) Creativity across the curriculum: A review and analysis of programmes designed to develop creativity. QCA, 2003.

Guilford, J. (1975) Creativity: A quarter century of progress. In: I. Taylor, and J. Getzels (Ed.), Perspectives in Creativity (pp. 37-59). Chicago, IL: Aldine Publishing Company.

Grainger, T., Barnes, J., \& Scoffham, S. (2004) A creative cocktail: Creative teaching in initial teacher education. Journal of Education for Teaching, 30, 243-253. doi:10.1080/0260747042000309475

Hayes, D. (2004). Understanding creativity and its implications for schools. Improving Schools, 7, 279-286. doi:10.1177/ 1365480204048930

H. Gibson, (2005). What creativity isn't: The presumptions of instrumental and individual justification for creativity in education. British Journal of Educational Studies, 53, 148-167. doi:10.1111/ j.1467-8527.2005.00288.x

Hussain, Z. (2004). Synergy of East and West for greater creativity. In: M. Fryer (Ed.), Creativity and Cultural Diversity (pp. 90-97). England: The Creativity Centre Educational Trust Press.

INCA (2009). Primary education: An international perspective. Internet Available: www.inca.org.uk/pdf/probe_singapore.pdf

Jeffrey, B. (2005). The redress of creative teaching and learning through specialist programmes and strategic partnerships. Paper given at the creativity in education seminar series. University of the West of England.
Jeffrey, B. (2006). Creative teaching and learning: Towards a common discourse and practice. Cambridge Journal of Education, 36, 399-414. doi:10.1080/03057640600866015

Kaila, H. (2005). Democratizing schools across the world to stop killing creativity in children: An Indian perspective. Counseling Psychology Quarterly, 18, 1-6. doi:10.1080/09515070500099728

Loveless (2002). Literature review in creativity, new technologies and learning Internet Available: www.future lab.org.uk/research/lit_revi ews.htm

MOE (2009). Desired outcomes of education. Internet Available: http:// www.moe.gov.sg/education/desired-outcomes/

NACCCE, (1999). All our futures: Creativity, culture and education. Internet Available: www.cypni.org.uk/downloads/alloutfutures.pdf

NCSL (2004). Developing creativity for learning in the primary school: A practical guide for school leaders. Internet Available: www.ncsl.org.uk/media-1 d7-d8-developing-creativity-in-the-primary-sc hool.pdf

NESTA (2009). Barriers to the realisation of creative ideas. National Endowment for Science, Technology and the Art.

Oral, G. (2006). Creativity of Turkish prospective teachers. Creativity Research Journal, 18, 65-73. doi:10.1207/s15326934crj1801 8

O'Donnell, S., \& Micklethwaite, C. (1999). Arts and creativity in education: An international perspective. Internet Available: www.inca.or g.uk/pdf/1999 creativity and arts.pdf

Parkhurst, H. (1999). Confusion, lack of consensus, and the definition of creativity as a construct. Journal of Creative Behavior, 33, 1-21

Parnes, S. (1970). Education and creativity. In: P. Vernon (Ed.), Creativity: Selected Readings, Penguin Books (pp. 341-354). Harmondsworth.

Poole, M. (1980). Creativity across the curriculum. London: George Allen and Unwin.

QCA (1999). The national curriculum: Handbook for primary teachers in England, key stages 1 and 2, QCA.

QCDA (2009). National Curriculum, Internet Available: http: //curri clum.qcda.gov.uk/key-stages-1-and-2/Values-aims-and-purposes/ind ex.aspx

Rogers, C. (1970). Toward a theory of creativity. In: P. Vernon, Ed., Creativity: Selected readings (pp. 137-151), Harmondsworth: Penguin Books,

Robinson, K. (2001). Unlocking creativity: A strategy for development. Belfast: Department of Culture Arts and Leisure.

Scoffham, S. (2003). Thinking creatively. Primary Geographer, 50, 4-6.

Shallcross, D. (1981). Teaching creative behaviour: How to invoke creativity in children of all ages. Prentice-Hall Inc.

Scottish Executive (2004). Cultural policy statement. Internet Available: www.scotland.gov.uk/culturalcommission/cultural/files/cultural\%20 policy $\% 20$ statement.pdf

Sinlarat, P. (2002). Needs to enhance creativity and productivity in teacher education throughout Asia. Asia Pacific Education Review, 3, 139-143. doi:10.1007/BF03024906

Tan, C. (2006). Creating thinking schools through knowledge and inquiry: The curriculum challenge for Singapore. The Curriculum Journal, 17, 89-105. doi:10.1080/09585170600682640

Treffinger, D. (1996) Creativity on the educational scene. Internet Available: http://buffalostate.edu/orgs/cbir/Readingroom/html/Treffinger $-96 . \mathrm{html}$

Turner-Bisset, R. (2007). Performativity by stealth: A critique of recent initiatives on creativity. Education 3-13, 35, 193- 203.

Talboys, M. (2004). QCA's creativity project. In: M. Fryer (Ed.), Creativity and Cultural Diversity (pp.181-188). England: The Creativity Centre Educational Trust Press Leeds.

Vong, K. (2008). Developing creativity and promoting social harmony: The relationship between government, school and parents' perceptions of children's creativity in Macao-SAR in China. Early Years, 28, 149-158. doi:10.1080/09575140802065599

Wilson, A. (2005). Creativity in primary education: Theory and practice (achieving QTS cross-curricular strand). Learning Matters Ltd.

Walberg, H. (1988). Creativity and talent as learning. In: R. Sternberg, (Ed.), The nature of creativity: Contemporary psychological perspectives (pp. 340-361). Cambridge: Cambridge University Press. 